\title{
Abundance, Diversity and Distribution of Phytoplankton in Coastal Water Adjacent to St. Martin's Island, Bangladesh
}

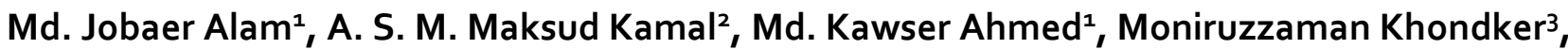 \\ Bijoy Mondal ${ }^{1}$ and Rafid Fayyaz ${ }^{1}$
}

\author{
${ }^{1}$ Department of Oceanography, University of Dhaka, Dhaka-1000, Bangladesh \\ ${ }^{2}$ Department of Disaster Science and Management, University of Dhaka, Dhaka-1000, Bangladesh \\ ${ }^{3}$ Department of Botany, University of Dhaka, Dhaka-1000, Bangladesh
}

Manuscript received: 20 July 2021; accepted for publication: 27 November 2021

\begin{abstract}
The purpose of this study was to ascertain the composition, abundance, and distribution of phytoplankton in the coastal waters of the Bay of Bengal, Bangladesh (BoB) adjacent to the St. Martin's Island. Samples were collected from 14 stations on low tide during the day time from March $13-19,2020$. In the present investigation, a total of 62 diatoms and 6 dinoflagellates were identified. Among diatoms, most dominant species were contributed by the genera Coscinodiscus followed by Chaetoceros, Thalassiosira, and Thalassionema. Among dinoflagellates, four species of Ceratium and one species from each of Dinophysis and Gonyaulax were identified. The cell count of total phytoplankton varied from $87,500-437,500$ in $\mathrm{d} / \mathrm{m}^{3}$ of sea water and the highest phytoplankton was found at station 4. Coscinodiscus was the most dominant genus of the centric diatoms in all the stations and its abundance ranged from 25,000-100,000 in $\mathrm{d} / \mathrm{m}^{3}$. The highest number of Coscinodiscus was found at station 4 . The result of this study showed that phytoplankton composition and their abundance varied from one station to another. But not much difference was observed among the ranges of physicochemical factors. Water temperature, salinity, $\mathrm{pH}$ and dissolved oxygen ranged from $26.5-27.17^{\circ} \mathrm{C}, 32.09-33.76 \mathrm{ppt}, 8.16-8.20$, and $5.85-6.12 \mathrm{mg} / \mathrm{l}$, respectively. The species richness factor and the diversity index factor as determined with the help of generic abundance which revealed the ranges from 1.51-4.93 and 1.52-2.22, respectively. The ranges of salinity and temperature recorded in the present investigation are quite consistent with the optimum ranges reported for marine habitats. The qualitative structure of phytoplankton shows similarities with other studies carried out in the BoB at different times. However, variability in the population density of phytoplankton in different studied stations may not be responsible for different water quality parameters rather than oceanic currents and tides.
\end{abstract}

Keywords: Phytoplankton, Abundance, Physicochemical factors, Coastal water, St. Martin’s Island, Bay of Bengal

\section{INTRODUCTION}

The Bay of Bengal (BoB), a semi-enclosed tropical marine ecosystem, is situated in the south of Bangladesh. It is a vast realm teeming with coral ecosystem of coastal and deep ocean environments, and the responses of marine life to anthropogenic activities. BoB harbors phytoplankton as the primary synthesizer of all organic materials in its estuaries and seas. These all in-turn connects the aquatic food chain of the sea and aid directly and indirectly in the formation of zooplankton, fish, and other living organisms (Castro and Huber, 2003). Phytoplankton is the determinant of fish production and a significant biological element in fish stock fluctuation,

Corresponding author: Md. Jobaer Alam

Email: jobaer_alam@du.ac.bd

DOI: https://doi.org/10.3329/dujees.v10i2.57512 contributing more than $40 \%$ of global carbon fixation (Kankal and Warudkar, 2012) and thereby lowering the global warming factor. It is estimated that phytoplankton produces roughly $80 \%$ of total atmospheric $\mathrm{O}_{2}$ in some places, and hence is responsible for the $\mathrm{O}_{2}: \mathrm{N}_{2}$ balance in the air (Castro and Huber, 2003). In addition, phytoplankton flora can be used to indicate the quality of water, which might be otherwise affected by the anthropogenic activities e.g., domestic wastes, industrial discharges, nutrient enrichment processes, etc. (Vitousek et al., 1997; Carter et al., 2005).

Knowledge on marine phytoplankton in Bangladesh is still sparse. However, there have been a few publications on it from the north-eastern coast of the BoB and Karnafuli estuary (Islam and Aziz, 1975, 1977). Ahmed et al. (2010) and Aziz et al. (2012) studied phytoplankton diversity from the southwestern coast of Bangladesh. The seasonality of coastal phytoplankton was also studied by Rahaman et 
al. (2013). Though a qualitative study of marine phytoplankton was carried out by Aziz (2005), this is in number very little when compared with the studies of phytoplankton from the freshwater habitats of Bangladesh (Islam and Khatun, 1966; Islam et al., 1991; Islam and Alfasane, 2002, 2003; Islam and Irfanullah 2003, 2005). St. Martin's Island, situated in the extreme southern fringe of the main territory of Bangladesh is the only coral island. The island has tremendous attraction to the tourists for visiting purposes. As a result, the coastal boundary of the island as well as the adjacent marine open waters is strongly affected by the anthropogenic activities. The fisheries and tourism sector of the island contributes 33.6 million USD/year to the local economy. Fisheries, a key economic sector, are generating annual direct use values of 13 million USD/year (Rani et al., 2020). Data on phytoplankton can aid in fishery and marine resource management and planning, as well as the preservation of ocean biogeochemical cycles. So, the main goal of this study was to determine the abundance and distribution of phytoplankton in the coastal waters of the St. Martin's Island so that the knowledge regarding the phytoplankton species and abundance can be used in the improvement of the mariculture of this important island.

\section{MATERIALS AND METHODS}

\section{Study Area}

In Bangladesh, St. Martin's Island, Teknaf, Cox's Bazar is also known as 'Narikel Jinjira' which is located in the northeastern part of the $\mathrm{BoB}$ between $20^{\circ} 34^{\prime}$ and $20^{\circ} 39^{\prime} \mathrm{N}$ and $92^{\circ} 18$ and $92^{\circ} 20^{\prime} \mathrm{E}$ (Figure 1). Myanmar's border (Arakan coastal plain) is barely 4.5 kilometers distant to the east, while the BoB is to the west and southwest. The current research was conducted in the coastal water adjacent to the St. Martin's Island (Figure 1).

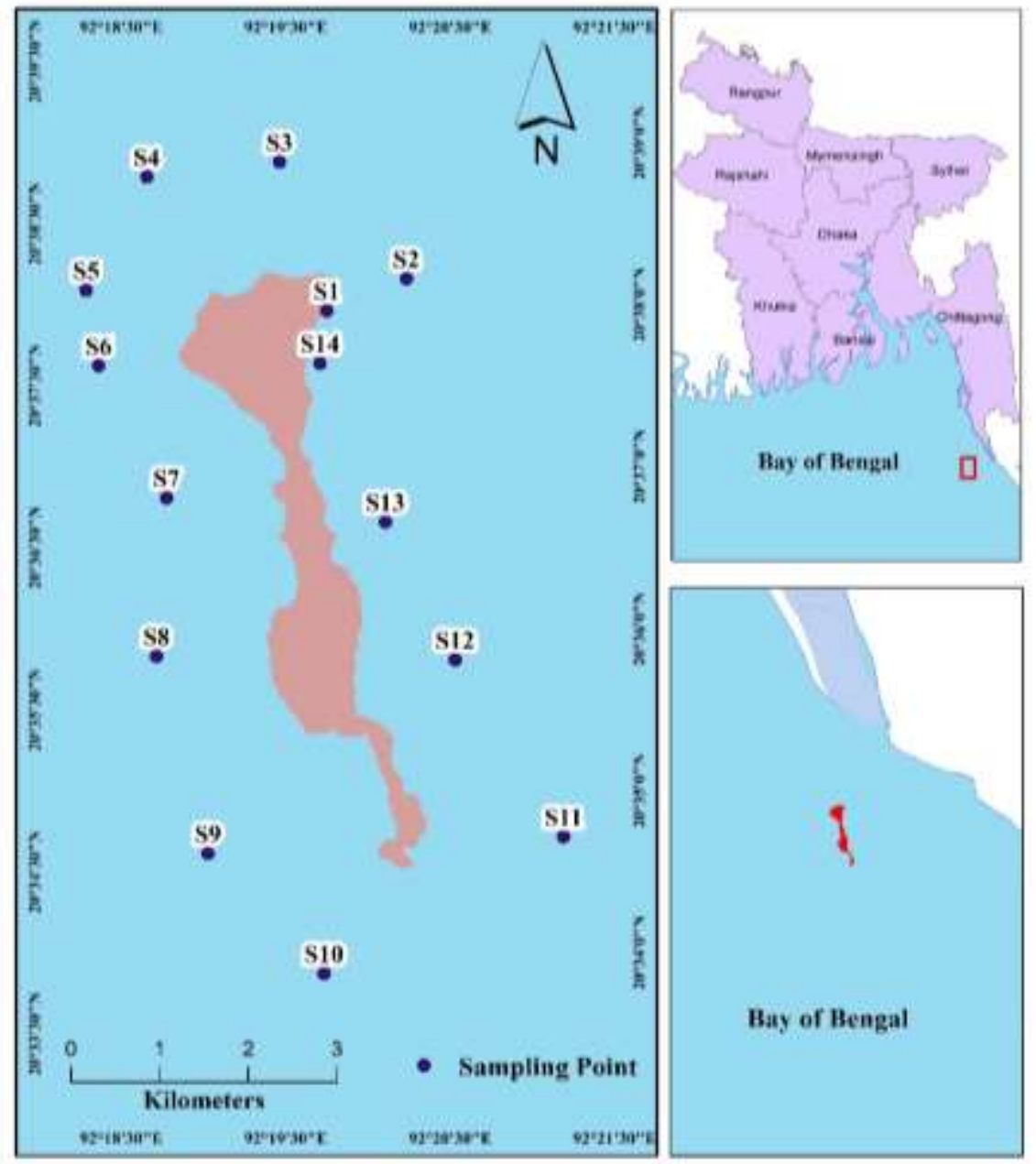

Figure 1: Showing the Sampling Stations in the Adjacent Marine Area of St. Martin's Island and the Location of the Island in the $\mathrm{BoB}$ 


\section{Sampling}

A total of 14 sampling stations (Station 1-14) were fixed to collect the samples for the present investigation (Figure 1). The sampling stations were visited from 13-19 March, 2020 and one sample from each station was collected. So, at the end there were 14 samples from 14 stations but on different dates covering the time period as mentioned (Table 1). Samples were gleaned from the stations during low tide and between 7:30 and 10.00 AM.

Table 1: Sampling Stations with Date and Time of Collection and the GPS Values

\begin{tabular}{lllll}
\hline Station No. & Date & Time & Latitude & Longitude \\
\hline 1 & $13 / 03 / 2021$ & $7: 28 \mathrm{am}$ & 20.6326923 & 92.3291468 \\
2 & $13 / 03 / 2021$ & $8: 02 \mathrm{am}$ & 20.6359811 & 92.3372028 \\
3 & $14 / 03 / 2021$ & $8: 18 \mathrm{am}$ & 20.6479894 & 92.3243359 \\
4 & $14 / 03 / 2021$ & $8: 34 \mathrm{am}$ & 20.6464468 & 92.3108763 \\
5 & $15 / 03 / 2021$ & $8: 56 \mathrm{am}$ & 20.6347993 & 92.3047317 \\
6 & $15 / 03 / 2021$ & $9: 30 \mathrm{am}$ & 20.6270468 & 92.3059843 \\
7 & $16 / 03 / 2021$ & $9: 26 \mathrm{am}$ & 20.6134481 & 92.3128833 \\
8 & $16 / 03 / 2021$ & $9: 50 \mathrm{am}$ & 20.5971542 & 92.3118536 \\
9 & $17 / 03 / 2021$ & $9: 30 \mathrm{am}$ & 20.5768836 & 92.3170856 \\
10 & $17 / 03 / 2021$ & $9: 56 \mathrm{am}$ & 20.5645229 & 92.3288508 \\
11 & $18 / 03 / 2021$ & $9: 24 \mathrm{am}$ & 20.5785989 & 92.3531412 \\
12 & $18 / 03 / 2021$ & $10: 02 \mathrm{am}$ & 20.5967917 & 92.3421398 \\
13 & $19 / 03 / 2021$ & $9: 33 \mathrm{am}$ & 20.6109784 & 92.3350769 \\
14 & $19 / 03 / 2021$ & $10: 06 \mathrm{am}$ & 20.6315248 & 92.3289363 \\
\hline
\end{tabular}

At each station the samples of phytoplankton were collected after passing $20 \mathrm{~L}$ of sea water through a 20 $\mu \mathrm{m}$ mesh phytoplankton net. The concentrate was decanted in a $250 \mathrm{~mL}$ plastic vial and preserved by adding Lugol's solution with gentle shaking. The samples were sealed, labeled with date and time and packed to transport. At the time of phytoplankton sample collection, in situ measurements of some physicochemical water quality parameters were also carried out. The surface water temperature was measured with the help of a mercury centigrade thermometer. The $\mathrm{pH}$ of water was measured using a portable digital $\mathrm{pH}$ meter (HANNA, pHep, Romania). The salinity and DO were measured using a refractometer and a portable digital DO meter, respectively (Agriculture Solutions, WL0020-ATC; HACH, HQ30d, USA). After collection of all the samples they were given an icepack and transported to the laboratory, Department of Oceanography, University of Dhaka within $24 \mathrm{~h}$. The analysis was started immediately and completed within the next $72 \mathrm{~h}$.

\section{Analyses of biological parameters}

A drop of plankton concentrate was placed onto a glass slide and covered with a coverslip. The preparation was then viewed via a student-microscope (Novel, N10E, China) to identify the genus and species. The organisms were identified using Tomas (1997); Hasle and Syvertsen (1997); Davis (1955) and Ahmed et al. (2009). The phytoplankton density was determined by using a Sedgewick Rafter Counting Chamber (S-R) with the help of student microscope at a magnification of $400 \times$. The $S-R$ cell was in rectangular chamber $(50 \times 20 \times 1 \mathrm{~mm})$ having 1000 $\mathrm{mm}^{2}$ area and $1000 \mathrm{~mm}^{3}$ in volume. On the grids of the cell, $1 \mathrm{ml}$ of concentrated sample was obtained. The cover slip was positioned diagonally across the cell which prevented the formation of air bubbles in the cell. To ensure a valid count, over filling of the SRCC was avoided. From each mount of S-R, the population density of phytoplankton was quantified based on genera. The final density of phytoplankton was counted by using the following formula.

Number of organisms $\left(\mathrm{m}^{-3}\right)=\left(\mathrm{C} \times \mathrm{V}_{1}\right) /\left(\mathrm{V}_{2} \times \mathrm{V}_{3}\right)$ where,

$\mathrm{C}=$ number of organisms counted,

$\mathrm{V}_{1}=$ Volume of concentrated sample $(\mathrm{ml})$,

$\mathrm{V}_{2}=$ Volume of sample counted $(\mathrm{ml})$,

$\mathrm{V}_{3}=$ Volume of filtered water by the plankton net $\left(\mathrm{m}^{3}\right)$.

By using the data on counting, Species richness $\left(D_{f}\right)$ was applied to determine the quantity of genera in the sample. The method of Margalef (1958) was used to calculate species richness in the sample. 
Species richness, $D_{\mathrm{f}}=(\mathrm{S}-1) / \ln (\mathrm{N})$

where,

$\mathrm{S}=$ number of genera in a sample

$\mathrm{N}=$ total number of genera

Shannon-Wiener index $(\mathrm{H})$ was used to evaluate the generic diversity in a sampling station. The following equation is used to calculate the ShannonWiener index:

Shannon-Wiener index, $\mathrm{H}=-\sum \mathrm{P}_{\mathrm{i}} \times \ln \left(\mathrm{P}_{\mathrm{i}}\right)$ and $\mathrm{P}_{\mathrm{i}}$ $=\mathrm{n} / \mathrm{N}$

where,

$\mathrm{n}=$ total number of individuals in a sample

$\mathrm{N}=$ total number of individuals

All the diversity calculation were performed considering the population density at genus level. However, with the help of literature and by observing the morphology, 68 species of phytoplankton were preliminarily identified from the study area. The species are listed in Table 3.

\section{Analysis of Data}

The data were digitized in the XL sheet (Microsoft excel, version-19) and then tables and figures were generated and drawn using international units of measurements.

\section{RESULTS}

\section{Water quality parameters}

The water temperature ranged from 26.50$27.17^{\circ} \mathrm{C}$. During the study, the maximum temperature was recorded at station 7 , while the lowest temperature was measured at station 1 . During the sample collection, the maximum and minimum DO levels were $6.02 \mathrm{mg} / \mathrm{L}$ and $5.83 \mathrm{mg} / \mathrm{L}$ at station 6 and station 1 respectively. The salinity concentration of the water ranged from $32.09-33.76 \mathrm{ppt}$, and the $\mathrm{pH}$ of the water ranged $8.16-8.22$.

Table 2: Water Quality Parameters in the Sampling Stations Around the St. Martin's Island.

\begin{tabular}{llllll}
\hline Station No. & Sample No. & Temperature $\left({ }^{\circ} \mathrm{C}\right)$ & Salinity $(\mathrm{ppt})$ & $\mathrm{pH}$ & DO $(\mathrm{mg} / \mathrm{L})$ \\
\hline 1 & 1 & 26.50 & 32.09 & 8.16 & 5.83 \\
2 & 2 & 26.62 & 32.69 & 8.20 & 5.91 \\
3 & 3 & 26.71 & 32.76 & 8.19 & 5.98 \\
4 & 4 & 26.80 & 32.71 & 8.16 & 5.98 \\
5 & 5 & 26.79 & 32.70 & 8.14 & 5.97 \\
6 & 6 & 27.01 & 32.76 & 8.17 & 6.02 \\
7 & 7 & 27.17 & 32.98 & 8.19 & 6.00 \\
8 & 8 & 27.09 & 33.62 & 8.20 & 6.01 \\
9 & 9 & 27.07 & 33.69 & 8.22 & 5.97 \\
10 & 10 & 27.03 & 33.76 & 8.21 & 5.98 \\
11 & 11 & 26.77 & 32.76 & 8.19 & 5.96 \\
12 & 12 & 26.71 & 32.59 & 8.18 & 5.88 \\
13 & 13 & 26.64 & 32.55 & 8.16 & 5.87 \\
14 & 14 & 26.57 & 32.10 & 8.17 & 5.84 \\
\hline
\end{tabular}

\section{Abundance, diversity and distribution of phytoplankton}

A total of 68 phytoplankton species under 22 genera were identified from 14 different sampling stations (Figure 2). From the recorded phytoplankton community, 62 species belonged to diatoms and 6 to dinoflagellates. In the community, the dominant genera were: Coscinodiscus, Chaetoceros, Thalassiosira, and Thalassionema. Among dinoflagellates, four species of Ceratium, one species from each of Dinophysis and Gonyaulax were recorded (Table 3 and Figure 3). The density of total phytoplankton in the community varied from 87,500 $437,500 \mathrm{ind} / \mathrm{m}^{3}$ and the highest value was found at station 4. Coscinodiscus is the most dominant in all the stations and the cell density of it ranged from 25,000-75,000 ind $/ \mathrm{m}^{3}$. Highest number of Coscinodiscus population was found at station 4 . 


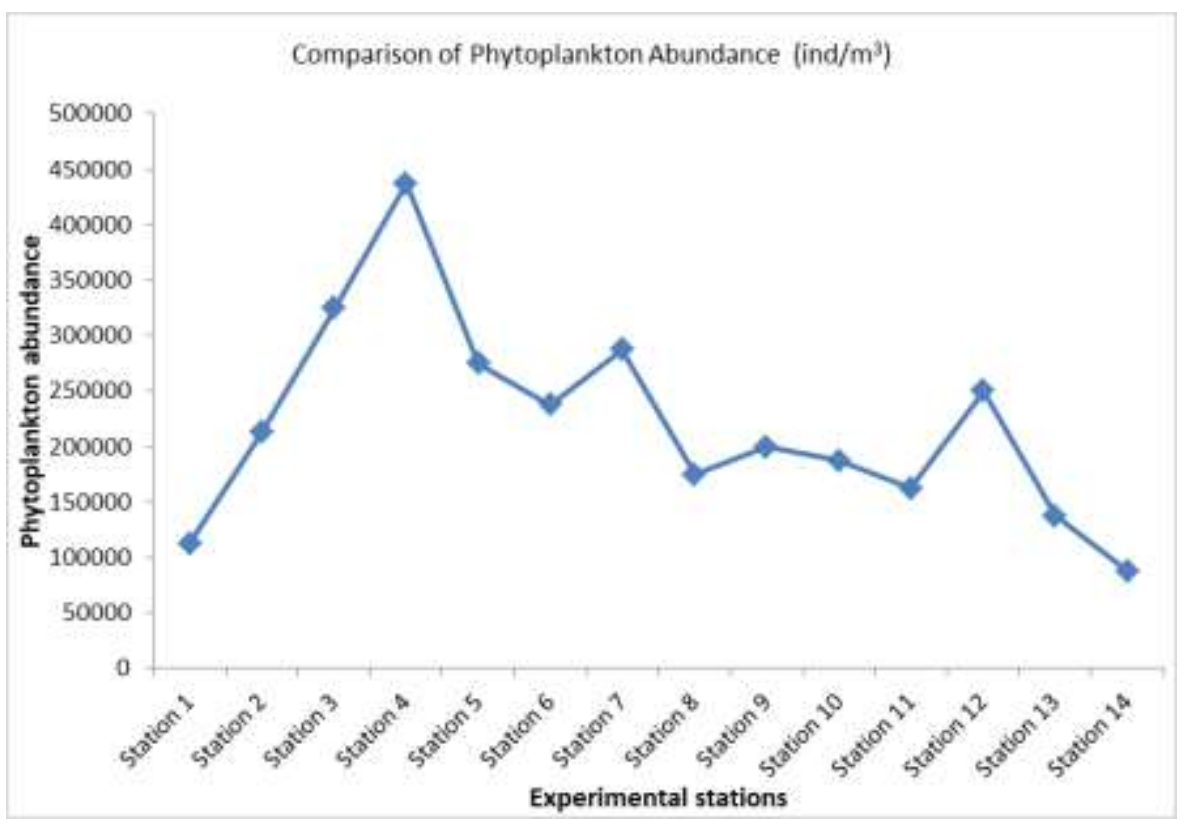

Figure 2: Comparison of Phytoplankton Abundance in All Sampling Stations.

Table 3: Phytoplankton Species Recorded from the Sea Water Adjacent to the St. Martin's Island.

\begin{tabular}{|c|c|c|c|}
\hline Class & Genus & Species & No. of species \\
\hline \multirow{13}{*}{ Bacillariophyceae } & Bacteriastrum & Bacteriastrum furcatum Shadboldt & 1 \\
\hline & Banquisia & Banquisia belgicae (Van Heurck) Paddock & 1 \\
\hline & Coscinodiscus & $\begin{array}{l}\text { Coscinodiscus radiatus Ehrenberg } \\
\text { C. marginatus Ehrenberg } \\
\text { C. granii LFGough } \\
\text { C. jonesianus (Greville) Ostenfeld } \\
\text { C. centralis } \text { Ehrenberg }\end{array}$ & 5 \\
\hline & Chaetoceros & $\begin{array}{l}\text { Chaetoceros neglectus Karsten } \\
\text { Ch. coarctatus Lauder } \\
\text { Ch. pseudocurvisetus Mangin } \\
\text { Ch. constrictus Gran } \\
\text { Ch. decipiens Cleve } \\
\text { Ch. lorenzianus Grunow } \\
\text { Ch. tenuissimus Meunier } \\
\text { Ch. danicus } \text { Cleve }\end{array}$ & 8 \\
\hline & Detonula & Detonula pumila (Castracane) Gran & 1 \\
\hline & Ditylum & $\begin{array}{l}\text { Ditylum spp. } \\
\text { Ditylum brightwellii (T. West) Grunow in Van Heurck }\end{array}$ & 4 \\
\hline & Eunotia & Eunotia sp. & 1 \\
\hline & Filodrillia & Filodrillia delicatula Laseron & 1 \\
\hline & Gyrosigma & Gyrosigma spp. & 3 \\
\hline & Lauderia & $\begin{array}{l}\text { Lauderia annulata Cleve } \\
\text { Lauderia sp. }\end{array}$ & 2 \\
\hline & Nitzschia & Nitzschia acicularis ( Kuetzing) W.Smith & 1 \\
\hline & Noctiluca & Noctiluca scintillans (Macartney) Kofoid \& Swezy & 1 \\
\hline & Odontella & $\begin{array}{l}\text { Odontella sinensis (Greville) Grunow } \\
\text { O. mobiliensis (J.W. Bailey) Grunow }\end{array}$ & 5 \\
\hline
\end{tabular}


Palmeria

Planktoniella

Rhizosolenia

Thalassionema

Thalassiosira
Odontella spp.

Palmeria hardmaniana Greville

Planktoniella sp.

Rhizosolenia formosa $\mathrm{H}$. Peragallo

$R$. castracanei $\mathrm{H}$. Peragallo

$R$. terperei H. Peragallo

$R$. imbricata Brightwell

$R$. robusta G. Norman ex Ralfs

Rhizosolenia spp.

Thalasiothrix sp.

Thalassionema bacillare (Heiden) Kolbe

T. frauenfeldii (Grunow) Tempère \& Peragallo

T. nitzschioides (Grunow) Mereschkowsky

T. longissima Cleve \& Grunow

Thalassionema spp.

Thalassiosira gravida Cleve

Th. australis M. Peragallo

Th. pseudonana Hasle \& Heimdal

Th. punctigera (Castracane) Hasle

Th. Proschrinae Makarova

Th. oestrupii (Ostenfeld) Proshkina-Lavrenko ex Hasle

Ceratium furca (Ehrenberg) Claparèdem \& Lachmann 4

Ce. Tripos (OF Müller) Nitzsch

Ce. Macroceros (Ehrenberg) Vanhöffen

Ce. Trichoceros (Ehrenberg) Kent

Dinophysis

Dinophysis tripos Gourret

1

Gonyaulax

Gonyaulax scrippsae Kofoid

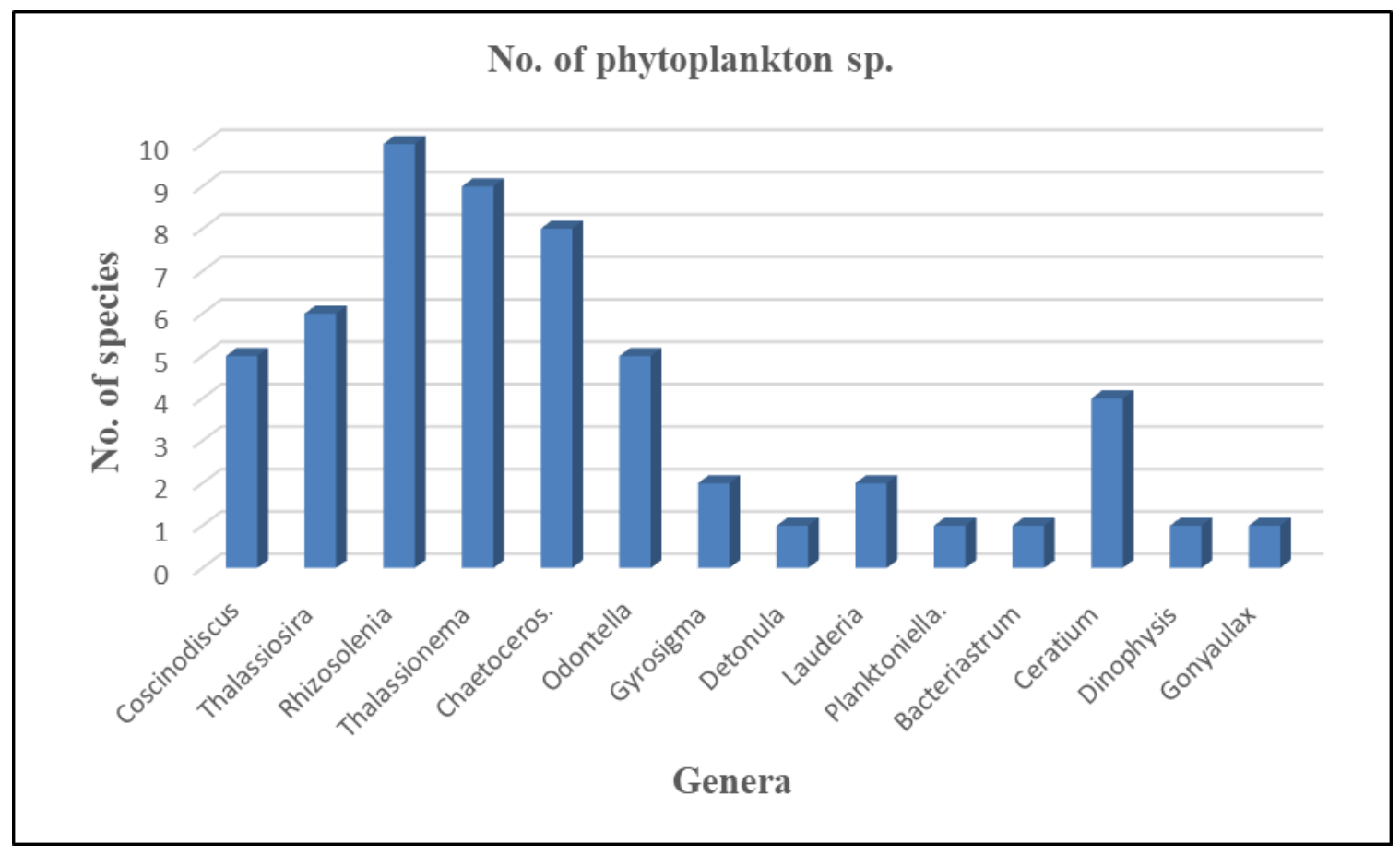

Figure 3: Comparison of Phytoplankton Species 
Table 4: Phytoplankton Population Density $\left(\mathrm{ind} / \mathrm{m}^{3}\right)$ at Generic Level from Different Stations

\begin{tabular}{|c|c|c|c|c|c|c|c|c|c|c|c|c|c|c|}
\hline Genera & $\begin{array}{l}\text { Station } \\
1\end{array}$ & $\begin{array}{l}\text { Station } \\
2\end{array}$ & $\begin{array}{l}\text { Station } \\
3\end{array}$ & $\begin{array}{l}\text { Station } \\
4\end{array}$ & $\begin{array}{l}\text { Station } \\
5\end{array}$ & $\begin{array}{l}\text { Station } \\
6\end{array}$ & $\begin{array}{l}\text { Station } \\
7\end{array}$ & $\begin{array}{l}\text { Station } \\
8\end{array}$ & $\begin{array}{l}\text { Station } \\
9\end{array}$ & $\begin{array}{l}\text { Station } \\
10\end{array}$ & $\begin{array}{l}\text { Station } \\
11\end{array}$ & $\begin{array}{l}\text { Station } \\
12\end{array}$ & $\begin{array}{l}\text { Station } \\
13\end{array}$ & $\begin{array}{l}\text { Station } \\
14\end{array}$ \\
\hline Coscinodiscus & 25000 & 50000 & 75000 & 100000 & 62500 & 50000 & 75000 & 37500 & 62500 & 50000 & 50000 & 50000 & 37500 & 25000 \\
\hline Thalassiosira & 12500 & 12500 & 25000 & 25000 & 37500 & 12500 & 37500 & 12500 & 25000 & - & 12500 & 25000 & 25000 & 12500 \\
\hline Rhizosolenia & - & - & - & 25000 & 12500 & 12500 & 12500 & 25000 & 12500 & 12500 & 12500 & 12500 & - & - \\
\hline Thalassionema & 12500 & 12500 & 12500 & 37500 & 25000 & 37500 & 25000 & 25000 & - & 25000 & 25000 & 25000 & 25000 & - \\
\hline Chaetoceros. & - & 37500 & 25000 & 25000 & 37500 & 25000 & 37500 & 25000 & 25000 & 12500 & 37500 & 37500 & 12500 & 12500 \\
\hline Odontella. & 12500 & 12500 & 12500 & 25000 & 12500 & 25000 & 12500 & 12500 & 12500 & - & - & 12500 & 12500 & - \\
\hline Gyrosigma. & - & 25000 & 25000 & 12500 & - & - & 12500 & - & - & - & 12500 & - & - & 12500 \\
\hline Detonula. & - & - & - & 12500 & 12500 & 12500 & 12500 & 12500 & - & - & - & 12500 & - & - \\
\hline Lauderia & & - & 12500 & 25000 & - & - & 12500 & - & 12500 & 12500 & - & - & - & - \\
\hline Planktoniella & 12500 & 12500 & - & 12500 & 12500 & 12500 & 12500 & - & 12500 & - & - & 12500 & - & 12500 \\
\hline Bacteriastrum & - & - & - & 12500 & - & 12500 & - & - & - & 12500 & - & 12500 & - & - \\
\hline Ceratium & - & - & 12500 & 25000 & 25000 & - & - & - & 12500 & - & - & 12500 & - & - \\
\hline Dinophysis & - & - & 12500 & 25000 & 12500 & - & - & - & - & 12500 & - & - & - & - \\
\hline Gonyaulax & - & 25000 & - & 12500 & 12500 & 12500 & - & - & - & 12500 & - & - & - & - \\
\hline Others & 25000 & 50000 & 62500 & 100000 & 87500 & 75000 & 62500 & 37500 & 50000 & 37500 & 25000 & 62500 & 25000 & 12500 \\
\hline
\end{tabular}

\section{Phytoplankton richness and Shannon-Wiener Index}

The results of diversity and richness calculation showed that station 1 has the lowest species richness (1.51) while the station 4 showed the highest richness of species (4.93) (Table 4). On the other hand, station
3 showed the lowest diversity index (1.46) and the highest was shown by station 4 (2.41). It means the carrying capacity of phytoplankton population at station 4 is higher compared to the other studied stations (Table 5).

Table 5: Phytoplankton Richness and Shannon-wiener Index.

\begin{tabular}{|c|c|c|c|c|}
\hline Experimental stations & $\begin{array}{l}\text { Total no. of } \\
\text { genus }\end{array}$ & Cells $/ \mathrm{m}^{3}$ & Species richness $D_{f}$ & $\begin{array}{l}\text { Shannon-wiener index } \\
\text { (H) }\end{array}$ \\
\hline 1 & 5 & 75000 & 1.51 & 1.56 \\
\hline 2 & 8 & 187500 & 2.65 & 1.93 \\
\hline 3 & 9 & 212500 & 3.03 & 1.46 \\
\hline 4 & 14 & 375000 & 4.93 & 2.41 \\
\hline 5 & 11 & 262500 & 3.79 & 2.22 \\
\hline 6 & 10 & 212500 & 3.41 & 2.15 \\
\hline 7 & 10 & 250000 & 3.41 & 2.05 \\
\hline 8 & 7 & 150000 & 2.27 & 1.86 \\
\hline 9 & 8 & 175000 & 2.65 & 1.87 \\
\hline 10 & 8 & 150000 & 2.65 & 1.91 \\
\hline 11 & 6 & 150000 & 1.89 & 1.63 \\
\hline 12 & 10 & 212500 & 3.41 & 2.15 \\
\hline 13 & 5 & 112500 & 1.52 & 1.52 \\
\hline 14 & 5 & 75000 & 1.52 & 1.56 \\
\hline
\end{tabular}



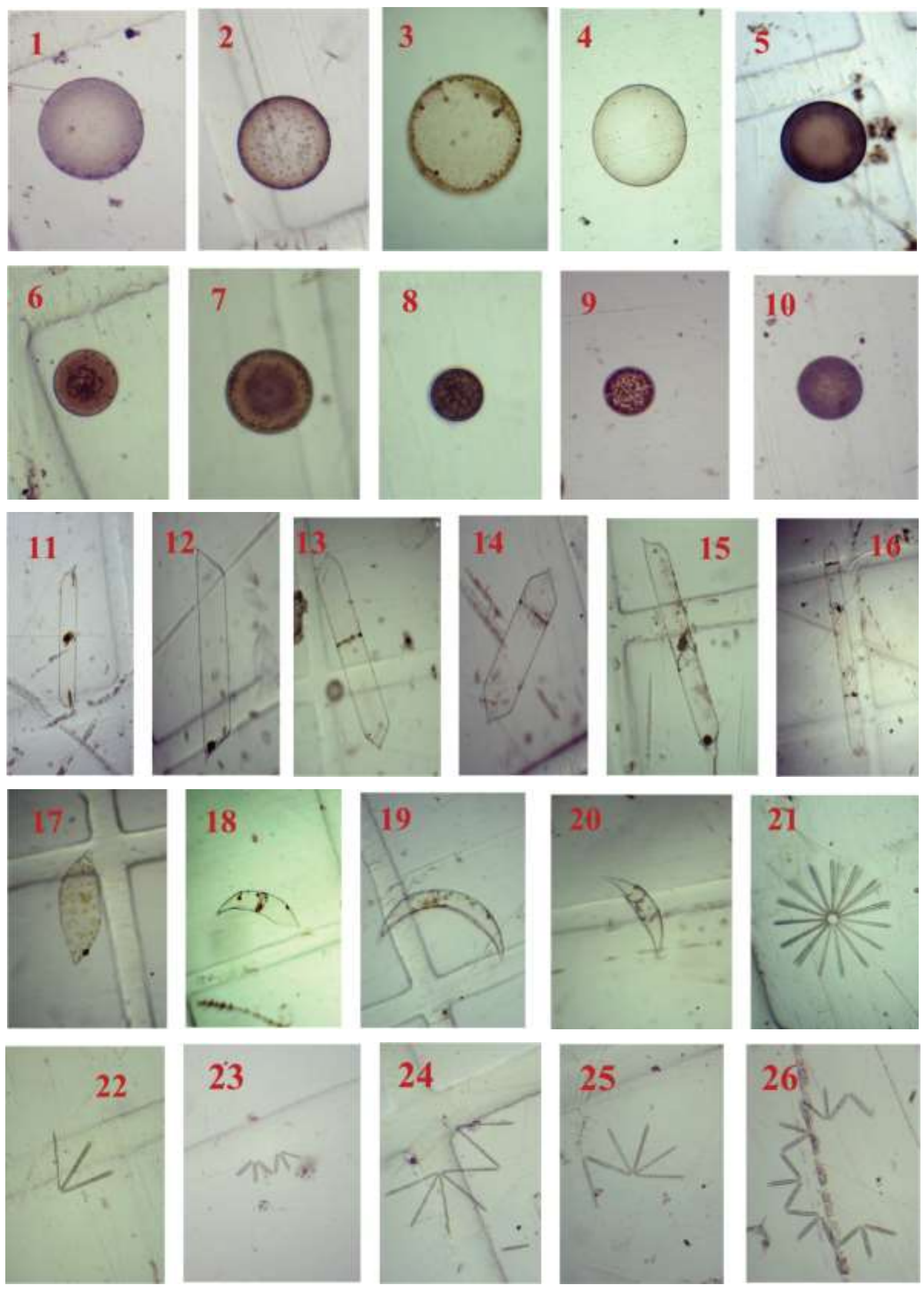

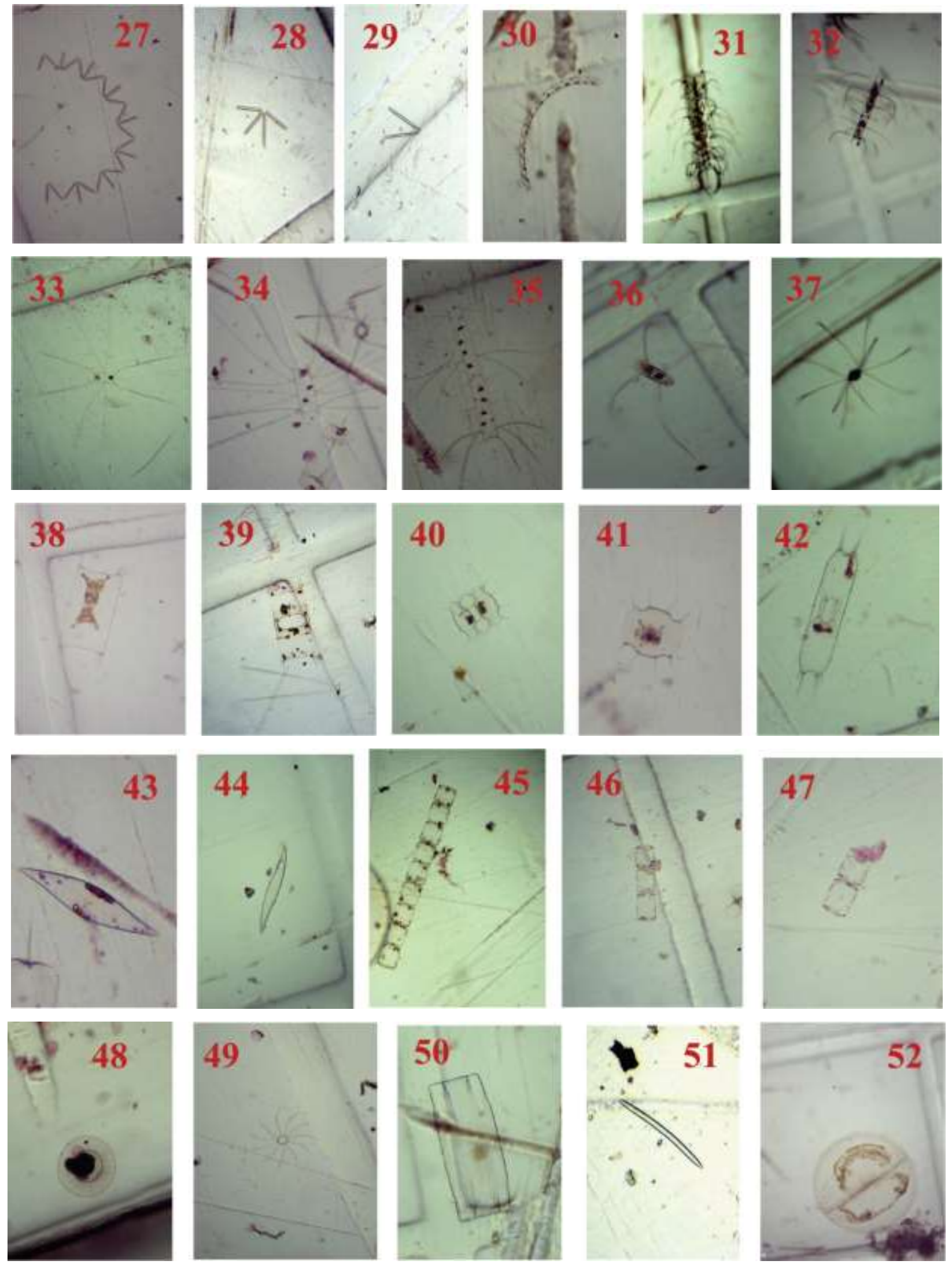

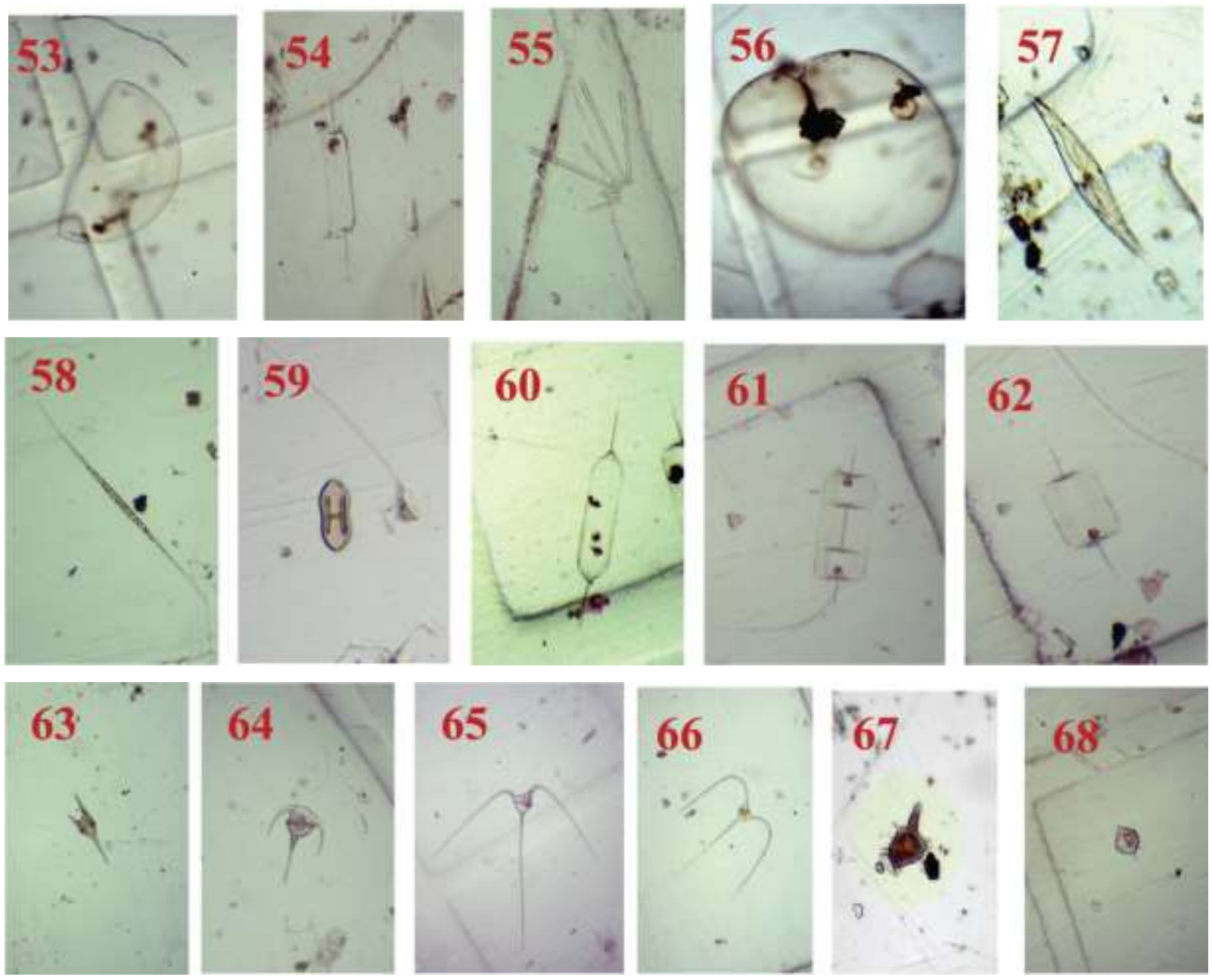

Figure 4 (1-26): 1) Cosinodiscus radiatus, 2) C. marginatus, 3) C. granii, 4) C. jonesianus, 5) C. centralis, 6) Thalassiosira gravida, 7) Th. australis, 8) Th. pseudonana, 9) Th. punctigera, 10) Th. proschrinae, 11) Rhizosolenia formosa, 12) $R$. castracanei, 13) Rhizosolenia sp., 14) R. terperei, 15) R. imbricata, 16) Rhizosolenia sp. (0.4x) 17) R. robusta, 18) Rhizosolenia sp., 19) Rhizosolenia sp., 20) Rhizosolenia sp., 21) Thalassionema frauenfeldii, 22) T. bacillare, 23) T. nitzschioides, 24) Thalassionema. sp. 25) Thalassionema sp., 26) Thalassionema sp.,

Figure 5 (27-52): 27) T. longissima, 28) Thalassionema sp., 29) Thalassionema sp., 30) Chaetoceros neglectus, 31) Ch. coarctatus, 32) Ch. pseudocurvisetus, 33) Ch. constrictus, 34) Ch. decipiens, 35) Ch. lorenzianus, 36) Ch. tenuissimus, 37) Ch. danicus, 38) Odontella sinensis, 39) Odontella. sp., 40) Odontella sp., 41) O. mobiliensis, 42) Odontella sp., 43) Gyrosigma sp., 44) Gyrosigma sp., 45) Detonnula pumila, 46) Lauderia annulata, 47) Lauderia sp., 48) Planktoniella sp. 49) Bacteriastrum furcatum, 50) Banquisia belgicae, 51) Eunotia sp., 52) Thalasiosira oestrupii,

Figure 6 (53-68): 53) Palmeria hardmaniana, 54) Ditylum sp., 55) Thalasiothrix sp., 56) Noctiluca scintillans, 57) Gyrosigma sp., 58) Nitzschia acicularis, 59) Filodrillia delicatula, 60) Ditylum sp., 61) D. brightwellii, 62) Ditylum sp., 63) Ceratium furca, 64) C. tripos, 65) C. macroceros, 66) C. trichoceros, 67) Dinophysis tripos, 68) Gonyaulax scrippsae

\section{DISCUSSION}

In this study a total number of 68 species of phytoplankton were identified from the Saint Martin's Island. From the recorded phytoplankton community 62 diatoms and 6 dinoflagellates were identified. Phytoplankton is mainly predominated by diatoms followed by dinoflagellates. Among diatoms, the most important species belonged to Coscinodiscus, Chaetoceros, Thalassiosira, and Thalassionema. Among dinoflagellates, 4 species of Ceratium and 1 species of each from Dinophysis and Gonyaulax were recorded. A total of 128 species of phytoplankton have been reported from Bay of Bengal of the coast of Bangladesh. Among them, 64 species of Bacillariophyceae and 10 species of Dinophyceae 
were recorded from the North-eastern Bay of Bengal by Islam and Aziz (1975). In addition, Aziz and Islam (1979) had recorded 22 species of marine dinoflagellates from the Bay of Bengal. When the qualitative records of phytoplankton from the $\mathrm{BoB}$ is compared, it could be seen that in the present investigation the species hierarchy follows a pattern of Rhizosolenia > Thalassionema > Chaetoceros > Thalassiosira while the pattern exhibited by the study of Islam and Aziz (1975) is Chaetoceros > Rhizosolenia $>$ Melosira $>$ Ditylum. Rhizosolenia and Chaetoceros appeared to be the dominant forms of phytoplankton in both the studies. The findings from Islam and Aziz (1975) seems to coincide with this study done in the adjacent waters of the St. Martin Island. Some other findings of phytoplankton are 61 genera in the lower Meghna river estuary (Sharif, 2007), 134 phytoplankton species in Sundarbans Mangrove Forest (Rahaman, 2013) and for the first time in coastal waters around Rushikulya estuary 149 phytoplankton species was reported (Baliarsingh, 2015).

In the present study, qualitatively, highest number of species was yielded by Rhizosolenia (10) followed by Chaetoceros (9), Thalassionema (8), and Thalassiosira (6).

Among diatoms, species of Consinodiscus, Chaetoceros, Thalassiosira, Pleurosigma and Thalassionema were predominant. Among dinoflagellates, two species from each of Ceratium, Protoperidinium, and one from each of Prorocentrum, Noctiluca and Gonyaulax were found. Station 4 hosted most of the genera that were found in the coastal waters of the island. The Margalleff species richness and the Shannon's diversity index of the studied stations ranged from 1.51-4.93, and 1.52-2.22. Motwani et al. (2014) reported ranges of the same indices as mentioned before, as 0.44-4.64, and 0.0983.28, respectively in the north eastern Arabian Sea. From this observation it could be said that the upper limit of the species richness value is quite consistent with that recorded for the present study. The maximum value of species diversity (3.22) recorded by Motwani et al. (2014) is lower (2.22) than that recorded for the present investigation. The physicochemical parameters recorded in this station were $26.8^{\circ} \mathrm{C}$ temperature, $32.71 \mathrm{ppt}$ salinity, $8.16 \mathrm{pH}$ and $5.98 \mathrm{mg} / \mathrm{L}$ DO. Islam and Aziz (1975) studied the phytoplankton along with the physicochemical parameters of water from the north eastern $\mathrm{BoB}$ and recorded the range of surface water temperature from 29.5-30.5 ${ }^{\circ} \mathrm{C}$. In their study the salinity, DO, $\mathrm{N}_{2}$ and phosphorus ranged from 20-30 ppt, 2.26-5.00 mg/l, $19-21 \mu \mathrm{g} / \mathrm{l}$ and $166-180 \mu \mathrm{g} / \mathrm{l}$, respectively. However, in the St. Martin's Island, Hossain and Islam (2006) reported sea surface temperature $26.0{ }^{\circ} \mathrm{C}$ and salinity $27.5 \mathrm{ppt}$ while the optimum values for these two parameters were reported as $20-30{ }^{\circ} \mathrm{C}$ and $32-37 \mathrm{ppt}$, respectively. The values for water temperature and salinity recorded in the present investigation are in consistent with the reported optimum for the sea water. Thus, it appears that the habitat studied is an ideal marine in nature and the species recorded were also characteristic to the habitats. It can be speculated that such combination of parameter values creates a favorable condition for most of the genera found in these waters but both extensive and intensive research needs to be undertaken considering the course of currents, tides and the concentration of nutrients.

\section{CONCLUSION}

This study contemplates comprehensive assessment of the marine water adjacent to the St. Martin's Island of Bangladesh and studies on the influence of the marine environment including biophysical aspects on these resources. The various phytoplanktons in the surface water of the island can be used as indicator of productivity, water quality, marine currents and climate modification. A total of 68 phytoplankton species were recorded from 14 different sampling stations. The total phytoplankton abundance varied from $87,500-437,500 \mathrm{ind} / \mathrm{m}^{3}$ and highest phytoplankton abundance was found at station 4. Coscinodiscus sp. is the most dominant in all the stations and the cell density of it ranged from 25,000$100,000 \mathrm{ind} / \mathrm{m}^{3}$. The results thus obtained show that phytoplankton composition and their abundance vary in the sampling stations. The phytoplankton quality and quantity recorded from the studied stations are quite consistent with other studies carried out so far in the Bay of Bengal, Bangladesh. The species richness and diversity index have similarities with those recorded elsewhere. The ranges for water temperature and salinity obtained in the present investigation fall within the optimum values quoted for sea water. The value of $\mathrm{pH}$ and dissolved oxygen recorded in the study stations are consistent too with other studies carried out in this part of the Bay of Bengal. However, 
from the present study no single factor could be found as responsible for the variability of phytoplankton population distribution.

Acknowledgement: The authors are thankful to the Department of Disaster Science and Management, and Department of Oceanography, University of Dhaka for providing laboratory facilities. Bangladesh Coast Guard is also thankfully acknowledged for assisting in data collection. Finally, the authors express their sincere thanks to University Grants Commission for funding to conduct the research.

\section{REFERENCES}

Ahmed, A., Hoque, S., Ohlson, M., Akanda, M.A.S. and Moula, M. G. (2010). Phytoplankton Standing Crop and its Diversity in the Buragauranga River Estuary in Relation to Chemical Environment. Bangladesh Journal of Botany 39: 143-151.

Ahmed, Z.U., Khondker, M., Begum, Z.N.T., Hassan, M.A., Kabir, S.M.H., Ahmad, M., Ahmed, A.T.A., and Rahman, A.K.A (eds). (2009). Encyclopedia of Flora and Fauna of Bangladesh, Vol. 4 Algae, CharophytaRhodophyta (Achnanthaceae-Vaucheriaceae). Asiatic Society of Bangladesh, Dhaka. 543 pp.

Aziz, A. (2005). Brackish Water Algae from Bangladesh. I. Biddulphia sp. Bangladesh Journal of Botany 34: 109114.

Aziz, A., Rahman, M. and Ahmed, A. (2012). Diversity, Distribution and Density of Estuarine Phytoplankton in The Sundarban Mangrove Forests, Bangladesh. Bangladesh Journal of Botany 41: 87-95.

Aziz, A. and Rahman, M. (2011). New record of planktonic diatoms from the Sundarbans mangrove forests, Bangladesh. Bangladesh Journal of Botany, 40(2): 163-169.

Aziz, A. and Islam, A.K.M.N. (1979). Marine dinoflagellates from the Bay of Bengal, Bangladesh. Journal of Bangladesh Academy of Sciences, 3(1\&2): 41-49

Baliarsingh, S.K., Srichandan, S., Naik, S., Sahu, K.C., Lotliker, A.A. and Kumar, T.S., (2015). Seasonal variation of phytoplankton community composition in coastal waters off Rushikulya Estuary, east coast of India.

Bettrons, D. A. S. and Castrejon, E.S. (1999). Structure of benthic diatom assemblages from a mangrove environment in a Mexican subtropical lagoon. Biotropica 31(1): 48 - 70. Chisholm, S. W., 2000.
Stirring times in the Southern Ocean. Nature, 407: 685-687.

Carter, C. M., Ross, A. H., Schiel, D. R., Howard-Williams, C., and Hayden, B. (2005). In situ microcosm experiments on the influence of nitrate and light on phytoplankton community composition. Journal of Experimental Marine Biology and Ecology, 326(1): 113.

Castro, P., and Huber, M.E. (2003). Marine biology (4 ${ }^{\text {th }}$ Edn.). McGraw-Hill Higher Education Companies Inc. North Ameriac. pp. 468.

Conway D.V.P., R. G. White, J. Hugues-Dit-ciles, C. P. Gallienne and D. B. Robins. (2003). Guide to the coastal and surface zooplankton of the South-Western Indian Ocean. Marine Biological Association of the United Kingdom. Occasional Publication No 15

Davis, C. (1955). The marine and fresh-water plankton. [East Lansing]: Michigan State University Press.

Hasle, G.R., Syvertsen, E.E., Steidinger, K.A., Tangen, K. and Tomas, C.R. (1996). Identifying marine diatoms and dinoflagellates. Elsevier.

Hendey, N. I. (1964). An introductory account of the smaller algae of British coastal waters. Part 5. Bacillariophyceae (diatoms) London. N.M.S.O. 317.

Hossain, M.M. and Islam, M.H. (2006). Status of the biodiversity of St. Martin's Island, Bay of Bengal, Bangladesh. Pakistan Journal of Marine Science 15(2): 201-210.

Islam, A. K. M. N., and A. Aziz. (1975). Study of Marine Phytoplankton from the North-Eastern Bay of Bengal, Bangladesh. Bangladesh Journal of Botany 4: 1-32.

Islam, A. K. M. N., and A. Aziz. (1977). Studies on the Phytoplankton of the Karnafuli River Estuary. Journal of Bangladesh Academy of Sciences 1: 141-154.

Islam, A.K.M. Nurul and Alfasane, M.A. (2002). New records of motile green algae for Bangladesh: Phacotus, Pteromonas and Thoracomonas, Bangldesh Journal of Plant Taxonomy 9(1): 15-18.

Islam, A.K.M. Nurul and Alfasane, M.A. (2003). Euglenophyceae from Barisal district, Bangladesh II: Lepocinclis, Strombomonas and Trachelomonas. Bangladesh. Bangladesh Journal of Plant Taxonomy 10(1): 15-26.

Islam, A.K.M. Nurul and Irfanullah, H.M. (2003). Freshwater algae of St. Martin's Island, Bangladesh - I. Bangladesh Journal of Plant Taxonomy 10(2): 33-45

Islam, A.K.M. Nurul and Irfanullah, H.M. (2005). Hydrobiological studies within the tea garden at 
Srimangal, Bangladesh. II. Algal flora (excluding Chlorophyceae). Bangladesh Journal of Plant Taxonomy 12(1): 33-52.

Islam, A.K.M. Nurul and Khatun, M. (1966). Preliminary studies on the phytoplanktons of polluted waters, Sci. Res. 3(2): 94-109

Islam, A.K.M. Nurul, Khondker, M. and Haque, S. (1991). Euglenoid algae of four polluted ponds in and around Dhaka city. Bangladesh Journal of Botany 20(1): 7-15

Islam AKMN and A Aziz (1979). Algal flora of Moheshkhali Island, Bangladesh. Dhaka University Studies Pt. B 27(2): 105-122.

Kankal, N.C. and Warudkar, S. (2012). Biodiversity of phytoplankton, zooplankton and zoobenthos in east coast, Bay of Bengal near Nellore, Andhra Pradesh (India).

Kasturirangan, L. R. (1963). A key for the identification of the more common planktonic Copepoda of Indian coastal waters. Indian National Committee on Oceanic Research. Council of Scientific and Industrial Research, New Delhi publication No. 2.

Margalef, R. (1958). Temporal succession and spatial heterogenity in natural phytoplankton. Perspectives in Marine Biology, 323-349.

McCreary, J. P., Kohler, K.E., Hood, R.R. and Olson, D.B. (1996). A four-component ecosystem model of biological activity in the Arabian Sea. Progress in Oceanography 37: 193-240.
Motwani, G., Raman, M., Matondkar, P., Parab, S., Pednekar, S., and Solanki, H. (2014). Comparison between phytoplankton bio-diversity various indices for winter monsoon and inter monsoon periods in north-eastern Arabian Sea. Indian Journal of GeoMarine Sciences 43(8): 1513-1518.

Nwankwo, D.I. (1984). Seasonal changes of phytoplankton of Lagos lagoon and the adjacent sea in relation to environmental factors. Ph.D. Thesis, University of Lagos. 447.

Rahaman, S. M. B., J. Golder, M. S. Rahaman, A. F. M. Hasanuzzaman, and K. A. Huq. (2013). Spatial and Temporal Variations in Phytoplankton Abundance and Species Diversity in the Sundarbans Mangrove Forest of Bangladesh. Journal of Marine Science: Research and Development 3: 126

Rani, S., Ahmed, M.K., Xiongzhi, X, Yuhuan, J., Keliang, C., Islam, M. (2020). Economic valuation and conservation, restoration \& management strategies of Saint Martini's coral island Bangladesh. Ocean \& Coastal Management 183. P. 105024. DOI.......

Sharif, A.S.M., Mahmood, N., Chowdhury, S.R. and Ullah, M.S., (2007). "Occurrence and distribution of phytoplankton in the lower Meghna river estuary, Bangladesh". Journal of Taxonomy and Biodiversity research. Biodiversity Research Group of Bangladesh. 2007 Vol 1, No 1, ISSN 1992-06. pp 1-7.

Vitousek, P. M., Mooney, H. A., Lubchenco, J. and Melillo, J. M. (1997). Human domination of Earth's ecosystems. Science, 277(5325): 494-499. 
